\title{
THE EFFECTS OF INSTRUCTIONAL STRATEGIES, COLLEGE DIVISION, AND GENDER ON STUDENTS’ PERFORMANCE IN COLLEGE ALGEBRA AT A UNIVERSITY IN SOUTH TEXAS
}

\author{
Andres Padilla-Oviedo ${ }^{1 *}$ \\ ${ }^{* 1}$ South Texas College Marie-Anne Mundy Texas A\&M University Kingsville Lori Kupczynski Texas A\&M University \\ Kingsville
}

*Corresponding Author: -

\begin{abstract}
: -
College Algebra courses have often served as gatekeepers to advancement toward a bachelor's degree for many undergraduate students in colleges and universities all over the United States. As College Algebra is a core requirement for graduation, it is very important that fail and drop rates for this course be minimized. The ability to pass this class has a direct influence on 4-year/6-year graduation rates as well as retention rates for undergraduate students. Research has been carried out throughout the United States in attempts to tackle this issue. The present study was designed to explore the differences in final grades in College Algebra courses regarding different instructional strategies, college division and gender. Test findings indicated that the performance of college students as measured by final grade in College Algebra courses was significantly different among diverse instructional strategies. In addition, the performance of college students as measured by final grade in College Algebra courses was not significantly different in each college division or gender for different instructional strategies. Findings provided useful information for increasing student retention in college mathematics courses. Students will be more likely to learn and retain mathematical knowledge when diverse approaches for teaching and learning mathematics are applied.
\end{abstract}




\section{INTRODUCTION}

Increasing dropout rates in higher education have become a major concern among university administrators and student associations (Gury, 2011). One reason for students dropping out of college is because of their lack of mathematical skills (Varsavsky, 2010).

Math skills are a factor in student dropout rates at the post-secondary level because of a systemic underpreparedness that causes them to enter college math with foundational deficiencies. College students' struggle to pass their mathematics courses, and because mathematics courses at the university level have become gatekeeper courses toward graduation, as well as more interesting degree specific courses, many students' dropout.

There is a need to create a broad scope of programs and interventions that work to improve students' ability to cope with college level educational requirements, especially in math, and to persist in their college education (Kezar, 2011). A blended instruction method for mathematics, consisting of a complementary learning environment and a computer-based section, is one such intervention that has demonstrated some success.

Education used to be instructor centered, but with the implementation of technology assisted learning provided by systems such as Assessment and LEarning in Knowledge Spaces (ALEKS), the situation has changed. ALEKS is a program that is utilized for the instruction of mathematics and science and provides students with personalized and selfpaced instruction. With ALEKS, students are given more control over the learning process. Consequently, there is an ongoing shift in the educational system from traditional methods to technology-assisted teaching (Gano, 2011).

With the addition of new computer-based technology assisted learning strategies in mathematics at postsecondary levels, this study was designed to explore the effects of technology assisted learning strategies, college division, and gender on passing or failing College Algebra courses. College Algebra courses are core requirements for graduation, and College Algebra has been a stumbling block for many students in respect to graduating from college. Specifically, the study examined the fall 2013 pass/fail/drop rates in College Algebra of students who were taught with different instructional strategies at a university in south Texas. The effects of college division and gender were also analyzed.

\section{LITERATURE REVIEW}

Often students are deficient in basic mathematical abilities upon entrance into higher education and universities are forced to correct students' deficiencies by offering remedial mathematics courses (Gillard, Robathan, \& Wilson, 2011). Higher education educators who work with freshman students continuously mention the decreased level of readiness of secondary school graduates and the qualitative change in the way that they think (Salkinov \& Burukhin, 2010).

\section{Curriculum and Technology in Higher Education}

Juan, Steegmann, Huertas, Martinez, and Simosa (2011) claimed that instruction has transformed with the utilization of technology. Juan et al. stated that the role of the instructor has changed with educational technology. Instruction used to be teacher-centered, and with the application of individualized computer-based learning, education becomes student-centered as students take control of their learning process. Mainly in the areas of statistics and mathematics, many university departments worldwide have been working on producing, developing, applying, and assessing new engaging curriculua that promote conceptual understanding instead of traditional focus. The objective is to increase students' critical thinking skills to solve real-life problems in the private and public sectors (Juan et al., 2011). Schreyer-Bennethum and Albright (2011) discovered that by increasing the amount of teachers who use and incorporate technology and interdisciplinary projects, the performance of learners improved.

\section{ALEKS in Mathematics}

Louisiana Technical University faculty used Assessment and LEarning in Knowledge Spaces (ALEKS) for Pre-Calculus students who were taking Calculus I and Calculus II (Hanna \& Carpenter, 2006). ALEKS was used as a tutoring system to help students review concepts in Pre-Calculus that are needed to succeed in Calculus I and II. Findings showed that 91 percent of learners who worked on ALEKS at least 23.5 hours throughout the semester earned a C, B, or A. Learners who did not use ALEKS did worse than those who used it, and there was a correlation between time spent in ALEKS and performance (Hanna \& Carpenter, 2006). Allen (2007) attributed performance in ALEKS to its emphasis in practice of every algebraic skill and constant assessment.

\section{Cooperative Learning}

Artzt and Newman (1990) described cooperative learning as small group activities aimed at completing a common goal. Johnson, Johnson, and Smith (1991) defined cooperative learning as the educational approach of small groups of students that maximized their learning by reflecting on each other's knowledge. Davidson (1990) considered cooperative learning a task for groups to discuss and possibly find a solution. In addition, students required face-to-face interaction, an environment that provides positive experiences by helping each other attain success (Davidson, 1990). Goodsell, Maher, and Tinto (1992) identified cooperative learning as a more general form of collaborative learning that was described as students working in groups, searching for a solution in order to deliver a product. According to Johnson et al. (1991), it is essential for teachers to be aware that cooperative learning requires all students in a small group to participate, and if one of the team members completed the work first, he or she has to help his or her team members to complete the work.

Dietz (1993) established that by using cooperative learning to teach approaches of choosing a sample, students created their own standardized sample methods, which demonstrates higher level critical thinking. Cooperative learning activities are connected to constructivism and are a large part of the current reform in higher education, particularly, in mathematics and science (Garfield, 1993). Educators need to design small group activities that transform the classroom 
into a community of students who dynamically work together to learn mathematics (Garfield, 1993). Thus, teachers using cooperative learning provided students with opportunities to teach each other, and research has shown that ensuring this method of secondary instruction is extremely effective in increasing student learning (McKeachie, Pintrich, Yi-Guang, \& Smith, 1986).

Zakaria, Chin, and Daud (2010) conducted a quasi-experimental study to determine the effects of cooperative learning on students' performance and attitudes in mathematics by conducting a $t$-test. The experimental group was composed of 44 students and a control group of 38 students (Zakaria et al., 2010).

Findings showed that cooperative learning improved students' performance and attitudes in mathematics (Zakaria et al., 2010). Furthermore, cooperative learning was recommended for mathematics teachers to incorporate in their classroom (Zakaria et al., 2010).

\section{Traditional}

Traditional lecture style in College Algebra courses at the university in south Texas was teacher centered. For instance, the instructor explains mathematical concepts and presents procedures on how to solve mathematical problems. Further, the instructor assigns homework, quizzes, tests and a common final exam. However, instructors have Academic Freedom's right, which means they can teach the class the way they want.

\section{CCA-FOCUS}

College Completion America Fundamentals of Conceptual Understanding \& Success (CCA-FOCUS) program started in 2008 as a summer bridge program (Loredo, 2012). The CCA-FOCUS members enrolled developmental mathematics students directly in an academic course, such as College Algebra, while providing just-in-time remediation in content, content specific support learning, and academic support.

Texas State University has continued to grow the FOCUS program on its campus, and in the fall of $2011,85 \%$ of the students who had enrolled in their program successfully completed developmental mathematics and received credit for College Algebra (Loredo, 2012).

\section{METHODOLOGY}

The purpose of this study was to determine the effects of instructional strategies, college division, and gender on the performance of college students as measured by pass/fail/drop in College Algebra courses. Instructional strategies include traditional lecture style, Assessment and LEarning in Knowledge Spaces (ALEKS) and College Completion America (CCA)-FOCUS in courses identified for mathematics requirements, namely College Algebra. The college divisions are College of Arts and Humanities, College of Science and Mathematics, College of Business Administration, College of Education, College of Engineering and Computer Science, College of Social and Behavioral Sciences, and College of Health Sciences and Human Services. The dependent variable considered was success as measured by pass/fail/drop.

\section{Population and Sample}

This study took place in a Hispanic serving university in south Texas in the middle of one of the rapidest developing areas in the United States. During the fall of 2013, the total enrollment at the university in south Texas was 20,053 students. The university in south Texas provides a choice of 54 bachelors, 55 masters, three doctoral programs, and two cooperative doctoral programs within seven colleges. The gender make-up of the university in the fall of 2013 was $45 \%$ male and $55 \%$ female. The race distribution was as follows: less than $1 \%$ American Indian or Alaskan Native, $1 \%$ Asian, $1 \%$ African American, 90\% Hispanic, <1\% Native Hawaiian or Other Pacific Islander, 3\% White, $<1 \%$ two or more races, $2 \%$ International and $3 \%$ race/ethnicity not reported. The average age of undergraduate students was 22 years and $17 \%$ were 25 years or older. The students who took College Algebra courses were generally undergraduates because these are core courses for graduation.

The sample based on the student population of this university in south Texas was designed as follows: the CCA-FOCUS has been implemented only once, so convenience sampling was used including all students who took those courses. The instructional strategies of ALEKS and traditional instruction had been implemented several times, and a randomization numbers table was used to select samples. Archival information was gleaned from students' transcripts who took College Algebra courses in the fall of 2013 taught by instructors who used instructional strategies, namely ALEKS, CCA-FOCUS, and traditional lecture style. The categorical dependent variables are scores of performance as measured by pass/fail/drop in College Algebra courses.

\section{Descriptive Statistics for Archived Data}

Descriptive statistics are provided for College Algebra undergraduate students regarding the variables in this study, including instructional strategies, college division and gender during the fall of 2013 (Tables 1.1 and 1.2).

There were 253 College Algebra students. Descriptive statistics are shown in Table 1.1. 
Table: 1.1 Frequency and Descriptive Statistics for College Algebra $(N=253)$

\begin{tabular}{lll}
\hline Variable & $\mathrm{N}$ & Percent \\
\hline Total & 253 & 100 \\
Final Grade & 29 & 11.5 \\
A & 56 & 22.1 \\
B & 58 & 22.9 \\
C & 44 & 17.4 \\
D & 33 & 13 \\
F & 33 & 13 \\
DR & & \\
Instructional Strategy & 34 & 13.4 \\
CCA-FOCUS & 123 & 48.6 \\
ALEKS & 96 & 37.9 \\
Traditional & & \\
College Division & 27 & 10.7 \\
College of Arts and Humanities & 43 & 17 \\
College of Sciences and Mathematics & 30 & 11.9 \\
College of Business Administration & 29 & 11.5 \\
College of Education & 55 & 21.7 \\
College of Engineering and Computer Science & 44 & 17.4 \\
College of Social and Behavioral Sciences & 25 & 9.9 \\
College of Health Sciences and Human Services & & \\
Gender & 121 & 47.8 \\
Male & 132 & 52.2 \\
Female & &
\end{tabular}

Descriptive statistics are provided in Table 1.2 for College Algebra undergraduate students' final grades regarding the variables in this study, including instructional strategies, college division and gender for the fall of 2013.

Table: 1.2 Frequency and Descriptive Statistics for College Algebra $(N=253)$

\begin{tabular}{lcccccc} 
Final Grade & A & B & C & D & F & DR \\
Instructional Strategy & 2 & & & & & \\
CCA-FOCUS & & 10 & 14 & 3 & 5 & 0 \\
ALEKS & 1730 & 31 & 20 & 10 & 15 \\
Traditional & & 1016 & 13 & 21 & 18 & 18 \\
College Division & & & & & & \\
College of Arts and Humanities & & 6 & 7 & 2 & 4 & 3 \\
College of Sciences and Mathematics & 4 & 7 & 12 & 6 & 8 & 6 \\
College of Business Administration & 8 & 5 & 7 & 3 & 1 & 6 \\
College of Education & 0 & 8 & 7 & 7 & 2 & 5 \\
College of Engineering and Computer Science & 6 & 15 & 11 & 10 & 10 & 3 \\
College of Social and Behavioral Sciences & 3 & 12 & 7 & 10 & 5 & 7 \\
College of Health Sciences and Human Services & 3 & 3 & 6 & 6 & 3 & 3 \\
Gender & & & & & & \\
Male & 10 & 28 & 27 & 21 & 19 & 16 \\
Female & 19 & 28 & 31 & 23 & 14 & 17 \\
\hline
\end{tabular}

\section{Inferential Statistics}

A Kruskal and Wallis $\mathrm{H}$ test was conducted to determine if there were differences in College Algebra final grades among groups that differed in their level of instructional strategy: the CCA-FOCUS ( $n=34)$, ALEKS ( $n=123)$ and traditional $(n=96)$ instructional strategies level groups. Distributions of College Algebra final grades were not similar for all groups as assessed by visual inspection of a boxplot. College Algebra final grades were significantly different among the different levels of instructional strategies: $\chi^{2}(2)=10.60, p=0.005$. Subsequently, pairwise comparisons were performed using Dunn's (1964) procedures with a Bonferroni correction for multiple comparisons. Adjusted $p$-values are presented. This post hoc analysis revealed statistical differences in College Algebra final grades between the CCA-FOCUS (mean rank $=144.46$ ) and traditional (mean rank $=108.46, p=0.012)$, and traditional and ALEKS (mean rank $=136.65$, $p=0.004$ ) instructional strategies groups but not between ALEKS and CCA-FOCUS. The means for students' final grades in College Algebra, the different instructional strategies were as follows: CCA-FOCUS $(M=4.03)$, ALEKS $(M=3.83)$ and traditional lecture style $(M=3.22)$. In other words, the mean of college students' final grades in College Algebra for CCA-FOCUS was higher than the mean for ALEKS, and the mean for ALEKS was higher than traditional lecture style. 
Findings showed that both instructional strategies CCA-FOCUS and ALEKS were significantly better than traditional lecture style in respect to final grades in College Algebra. Tables 1.3 and 1.4 display these findings.

Table: 1.3 Kruskal and Wallis H test for College Algebra

\begin{tabular}{llll}
\hline Variable & $\mathrm{N}$ & Mean Rank & Mean \\
\hline Instructional Strategy & & & \\
CCA-FOCUS & 34 & 144.46 & 4.03 \\
ALEKS & 123 & 136.65 & 3.83 \\
Traditional & 96 & 108.46 & 3.22 \\
\hline
\end{tabular}

Table: 1.4 Pairwise Comparisons for College Algebra

\begin{tabular}{lll}
\hline Variable & Test Statistic & $p$-value \\
\hline Instructional Strategy Comparisons & & \\
CCA-FOCUS vs ALEKS & 7.81 & 0.575 \\
CCA-FOCUS vs Traditional & 35.998 & 0.012 \\
ALEKS vs Traditional & 28.188 & 0.004 \\
\hline
\end{tabular}

A Kruskal and Wallis $\mathrm{H}$ test was used to determine if there were differences in College Algebra final grades between groups that differed in their level of college division: College of Arts and Humanities $(n=27)$, College of Sciences and Mathematics $(n=43)$, College of Business Administration $(n=30)$, College of Education $(n=29)$, College of Engineering and Computer Sciences $(n=55)$, College of Social and Behavioral Sciences $(n=44)$, and College of Health Sciences and Human Services $(n=25)$ college division level groups. Distributions of College Algebra final grades were similar for all groups as assessed by visual inspection of a boxplot. College Algebra final grades in the college divisions increased respectively: College of Sciences and Mathematics (Mdn

=3.50), College of Health Sciences and Human Services $(M d n=3.54)$, College of Education $(M d n=3.57)$,

College of Social and Behavioral Sciences $(M d n=3.59)$, College of Engineering and Computer Sciences $(M d n=3.90)$, College of Arts and Humanities $(M d n=4.15)$, and the College of Business Administration $(M d n=4.25)$ college division groups, but no significant differences were found, $\chi^{2}(6)=4.90, p=0.56$. Findings showed that the performance of college students as measured by final grade in College Algebra courses for the three instructional strategies, namely ALEKS, CCA-FOCUS, and traditional lecture style, were not significantly different for each college division.

A Kruskal and Wallis $\mathrm{H}$ test was used to determine if there were differences in College Algebra final grades between groups that differed in their level of gender: male $(n=121)$, and female $(n=132)$ gender level groups. Distributions of College Algebra final grades were similar for all groups as assessed by visual inspection of a boxplot. College Algebra final grades increased from male $(M d n=3.63)$ to female $(M d n=3.87)$ gender groups, but the differences were not significantly different: $\chi^{2}(1)=1.21, p=0.27$.

\section{CONCLUSION}

The sample for this study of undergraduate students in mathematics was predominantly Hispanic. The final grades for students in College Algebra courses who were taught using CCA-FOCUS, ALEKS, and traditional lecture style as instructional strategies were significantly different. CCA-FOCUS had the higher mean among three instructional strategies for College Algebra. However, both CCA-FOCUS and ALEKS performed significantly better than traditional lecture style in College Algebra.

The difference of instructional strategy between CCA-FOCUS and ALEKS in College Algebra courses was that CCA-FOCUS instructors used cooperative learning and did not use artificial intelligence as ALEKS did. Moreover, there were instructors using ALEKS who were lecturing small groups of students who showed difficulties in understanding ALEKS' explanations, but there were some instructors who did not lecture but tutored students independently.

The finding that students' mathematics final grades were higher using ALEKS than using traditional lecture style as an instructional strategy was supported by research that was conducted by Allen (2007); Hagerty, Smith, and Goodwin (2010); Hampikian, Gardner, Moll, and Schrader (2006); Hanna and Carpenter (2006); and Hasselbring (1988) because their findings reported gains in learning when ALEKS was used.

The performance of college students as measured by final grade in College Algebra courses for the three instructional strategies, ALEKS, CCA-FOCUS and traditional lecture style, was not significantly different for each college division. One reason for the lack of significant differences among college divisions in College Algebra might be the small sample size because 38 of the 42 cells had very few or no observations, as shown in Table 1.2.

The last comparison between performance of female and male college students as measured by final grade in College Algebra courses showed no significant differences. Peters (2013) examined differences between genders and interactions among classroom attainment, self-efficacy and climate for mathematics classes in College Algebra. Findings showed that females had lower mathematics self-efficacy than males, but results were not statistically significant in respect to mathematics attainment. Peters suggested that her study must be duplicated utilizing a more culturally diverse learner sample. The present study provided the same findings as the study conducted by Peters because we found that there was no significant difference in student achievement in College Algebra courses in respect to gender. However, OlszewskiKubilius and Lee (2011) studied gender differences in learners' performance in mathematics versus their performance in 
verbal areas as well as the stated proportions of females and males for particular scoring stages still existing from 2000 to 2008. Their findings indicated that males outperformed females in the STEM field for gifted students irrespective of age. However, females did better than males in verbal examinations. These differences between genders remained stable over a nine-year period with little effect sizes. In verbal areas, ratio of females to males was two to one. In STEM areas, ratio of males to females was three to one. In addition, there was a difference in performance by ethnicity and household income levels.

Goodsell, Maher, and Tinto (1999) identified cooperative learning with students working in groups searching for a solution in order to deliver a product. CCA-FOCUS was based on cooperative learning, which supported small group activities that maximized learning by making students teach each other. Students who were taught using ALEKS as an instructional strategy scored significantly better than students who were taught using traditional lecture style as an instructional strategy in College Algebra courses. ALEKS uses Knowledge Space Theory to provide artificial intelligence that helps students learn at their own pace.

According to the present study, CCA-FOCUS provided better student final grades in College Algebra courses. However, instructors need to be able to facilitate the course using cooperative learning. Consequently, educational leaders need to provide the appropriate training to instructors in order to successfully implement cooperative learning in these courses. In addition, students who were taught using ALEKS as an instructional strategy scored significantly better than students who were taught using traditional lecture style as an instructional strategy in College Algebra courses. Consequently, educational leaders can enhance learning by using ALEKS and connect it to cooperative learning. The use of personalized learning is increasing in higher education, particularly in mathematics freshman courses. It is crucial that educational leaders provide mathematics' faculties with the training necessary to be up to date with technology. Thus, students can take advantage of programs such as ALEKS in College Algebra courses to enhance their learning. Faculty need to be provided with teaching strategies such as CCA-FOCUS where cooperative learning is used, and students can take advantage of learning not only from their teacher but also from their classmates. Educators need to continue improving instructional strategies by finding the best attributes of each and integrating them in one, such as combining ALEKS with lecture.

The following are recommendations for future research:

1. More research is needed among different teaching delivery methods, such as face-to-face, hybrid, online, and massive open online learning courses.

2. More investigation is needed to understand the factors of each instructional strategy that increases and decreases student achievement.

3. More research is needed on students' knowledge of their freedom to take different mathematics courses.

4. The sample was taken from one university using two mathematics courses during the fall of 2013; it is recommended that the study be run again using spring and summer semesters.

5. Similar studies need to be carried out in other universities with larger sample sizes to strengthen the literature in this area, and qualitative research might produce more detailed results and strengthen this study.

6. More investigation is needed in respect to college division impact on student achievement.

\section{REFERENCES}

[1].Assessment and LEarning in Knowledge Spaces (ALEKS). (2014). Overview of ALEKS. Retrieved from http://www.aleks.com/about_aleks/overview.

[2].Albert, D., \& Hockemeyer, C. (1997). Adaptive and dynamic hypertext tutoring systems based on knowledge. In B. D. Boulay, \& R. Mizoguchi, Artificial intelligence in education: Knowdege and media in learning systems (pp. 553555). Amsterdam, NL: IOS Press.

[3].Albert, D., \& Lukas, J. (Eds). (1999). Knowledge spaces: Theories, empirical research, and applications. Mahwah, NJ: Erlbaum.

[4].Allen, J. (2007). Perkins Reports. Retrieved from: http://faculty.ccri.edu/joallen/Research/ Reports_main.htm.

[5].Andersen, M. H. (2011). The world is my school: Welcome to the era of personalized learning. Futurist, 45(1), 12-17.

[6].Archer, K. J., Lemeshow, S., \& Hosmer, D. W. (2007). Goodness-of-fit tests for logistic regression models when data are collected using a complex sampling design. Computational Statistics \& Data Analysis, 51(9), 4450-4464.

[7].Artzt, A., \& Newman, C. (1990). How to use cooperative learning in the mathematics class. Reston, VA: National Council of Teachers of Mathematics.

[8].Barefoot, B. O. (2004). Higher education's revolving door: Confronting the problem of student drop out in U.S. colleges and universities. Open Learning, 19(1), 9-17.

[9].Bartlett, J. E., Kotrlik, J. W., \& Higgins, C. C. (2001). Organizational research:

[10]. Determining appropriate sample size in survey research. Information Technology, Learning, and Performance Journal, 19(1), 43-50. Retrieved from http://www.ncde.appstate.edu/reserve_reading/what_works.htm.

[11]. Boylan, H. R., \& Saxon, D. P. (2002). What works in remediation: Lessons from 30 years of research. Paper prepared for The League for Innovation in the Community College. Retrieved from.

[12]. http://www.hawaii.edu/offices/cc/docs/goal_a/What_Works_in_Remediation.pdf.

[13]. Booth, C., \& Brecher, D. (2014). Ok, library. College \& Research Libraries News, 7(5), 234-239.

[14]. Brookhart, S. M. (1999). The art and science of classroom assessment: The missing part of pedagogy. ASHEERIC Higher Education Report, 27(1). ERIC Clearinghouse on Higher Education. 
[15]. Bulut, M., \& Bulut, N. (2011). Pre service teachers' usage of dynamic mathematics software. The Turkish Online Journal of Educational Technology, 10(4), 294-299.

[16]. Burns, R., \& Burns, R. (2008). Business research methods and statistics using SPSS. London, UK: Sage Publications Ltd.

[17]. Burrill, G. F. (1998). A “snapshot” of our country's mathematics education. Momentum, 29(3), 60-62.

[18]. Casazza, M. E. (1998). Strengthening practice with theory. Journal of Developmental Education, 22(2), 1-11.

[19]. Chin, S. (2014). Mobile technology and gamification: The future is now! Proceedings of the Fourth Annual Conference: Digital Information, and communication technology and Its Applications, May 2004. Piscataway, NJ: Institute of Electrical and Electronics Engineers.

[20]. Cohen, L., Manion, L., \& Morrison, K. (2000). Research methods in education (5 ${ }^{\text {th }}$ ed.). London: Routledge Falmer.

[21]. Cole, M., John-Steiner, V., Scribner, S., \& Souberman, E. (Eds.). (1978). L.S. Vygotsky, mind in society: The development of higher processes. Cambridge, MA: Harvard University Press.

[22]. Conlan, O., O'Keeffe, I., Hampson, C., \& Heller, J. (2006). Using knowledge space theory to support learner modeling and personalization. World Conference on E-Learning in Corporate, Government, Healthcare, and Higher Education 2006, (1), 1912-1919.

[23]. Corbishley, J. B., \& Truxman, M. P. (2010). Mathematical readiness of entering college freshmen. School of Science and Mathematics, 110(2), 71-85.

[24]. Creswell, J. W. (2009). Research design qualitative, quantitative and mixed methods approaches (3 ${ }^{\text {rd }}$ ed.). Thousand Oaks, CA: Sage Publication Inc.

[25]. Csikszentmihalyi, M. (1975). Beyond boredom and anxiety. San Francisco, CA: Jossey-Bass.

[26]. Davidson, N. (1990). Cooperative learning in mathematics: A handbook for teachers. Location: AddisonWesley Publishing Company, Inc.

[27]. Davies, R. S., Dean, D. L., \& Ball, N. (2013). Flipping the classroom and instructional technology integration in a college-level information systems spreadsheet course. Educational Technology Research and Development, 61(4), 563-580.

[28]. Davis, J. (2011). Student as institutional mirror: What campuses can learn from nontraditional populations. About Campus, 16(4), 2-10.

[29]. Demski, J. (2012). This time it's personal. T.H.E. Journal, 39(1), 32-36.

[30]. Dietz, E. J. (1993). A cooperative learning activity on methods of selecting a sample, The American Statistician, 47, 104-108.

[31]. Doignon, J. P., \& Falmagne, J. C. (1985). Spaces for the assessment of knowledge. International Journal of ManMachine Studies, 23(2), 175-196.

[32]. Doignon, J., \& Falmagne, J. (1999). Knowledge spaces. New York, NY: Springer.

[33]. Duncan, A. (2010). Learning, engage and empower: National educational technology plan. Retrieved from http://www.ed.gov/technology/netp-2010/learning-engage-and-empower.

[34]. Ertmer, P. A., \& Newby, T. J. (1993). Behaviorism, cognitivism, constructivism: Comparing critical features from an instructional design perspective. Performance Improvement Quarterly, 6(4), 50-70.

[35]. Falmagne, J. C., Cosyn, E., Doignon, J. P., \& Thiéry, N. (2006). The assessment of knowledge, in theory and in practice. In B. Garter and Likwida (Eds.) Formal concept analysis (pp. 61-79). Irvin, CA: University of California.

[36]. Ferreira, J. (2013). Heavy duty infrastructure for the adaptive world. Retrieved from http://www.knewton.com/platform/.

[37]. Gano, L. R. (2011). Fitting technology to the mathematics pedagogy: Its effect on students' academic achievement. Journal of College Teaching \& Learning, 8(11), 29-36.

[38]. Garcia, M. (2010). When Hispanic students attempt to succeed in college, but do not. Community College Journal of Research and Practice, 34, 839-847.

[39]. Garfield, J. (1993). An authentic assessment of students' statistical knowledge. National Council of Teachers of Mathematics, 187-196.

[40]. Garfield, J., \& Ben_Zvi, D. (2009). Helping students develop statistical reasoning: Implementing a statistical reasoning learning environment. Teaching Statistics, 31(3), 72-77.

[41]. Garfield, J., Le, L., Zieffler, A., \& Ben-Zvi, D. March, (2014). Developing students' reasoning about samples and sampling variability as a path to expert statistical thinking. Educational Studies in Mathematics, 116.

[42]. Garfinkel, S. (2014). Glass, darkly. Technology Review, 117(2), 70-77.

[43]. Gay, L. R., Mills, G. E., \& Airasian, P. (2006). Educational research: Competencies for analysis and applications ( $8^{\text {th }}$ ed.). Upper Saddle River, NJ: Pearson.

[44]. Gillard, J., Robathan, K., \& Wilson, R. (2011). Measuring the effectiveness of a mathematics support service:

[45]. An e-mail survey. Teaching Mathematics and Its Applications, 30, 43-52.

[46]. Giovanni, P., Pirrone, R., \& Rizzo, R. (2008). A KST-based system for student tutoring. Applied Artificial Intelligence, 22(4), 283-308.

[47]. Glass, R. D., \& Nygreen, K. (2011). Class, race and the discourse of "college for all:" A response to "schooling for democracy." Democracy \& Education, 19(1), 1-8.

[48]. Gradel, K., \& Edson, A. J. (2011). Cooperative learning: Smart pedagogy and tools for online and hybrid courses. Journal of Educational Technology Systems, 39(2), 193-212.

[49]. Goodsell, A., Maher, M., \& Tinto, V. (1992). Collaborative learning: A sourcebook for higher education. University Park, PA: National Center on Postsecondary Teaching, Learning and Assessment. 
[50]. Goodwin, B., \& Miller, K. (2013). Evidence on flipped classrooms is still coming in. Educational Leadership, 70(6), 78-80.

[51]. Gribbons, B., \& Herman, J. (1997). True and quasi-experimental designs. Practical Assessment, Research \& Evaluation, 5(14).

[52]. Gury, N. (2011). Dropping out of higher education in France: A micro-economic approach using survival analysis. Education Economics, 19(1), 51-64.

[53]. Hagerty, G., Smith, S., \& Goodwin, D. (2010). Redesigning college algebra: Combining educational theory and web-based learning to improve student attitudes and performance. Philadelphia, PA: LTD. Retrieved from http://www.tandfonline.com/loi/upri20.

[54]. Halinski, R. S., \& Feldt, L. S. (1970). The selection of variables in multiple regression analyses. Journal of Educational Measurement, 7(3), 151-158.

[55]. Hampikian, J., Gardner, J., Moll, A., Pyke, P., \& Schrader, C. (2006, June). Integrated pre-freshman engineering and precalculus mathematics. Proceedings of the 2006 Annual Conference of the American Society for Engineering Education, Chicago, IL.

[56]. Handal, B., \& Herringhton, A. (2003). Re-examining categories of computer-based learning and mathematics education. Contemporary Issues in Technology and Teacher Education, 3(3).

[57]. Hanna, R. E., \& Carpenter, J. (2006, June). Predicting student preparedness in calculus. Proceedings of the 2006 American Society for Engineering Education Annual Conference. Chicago, IL.

[58]. Hardy, M. E. (2004). Use and evaluation of the ALEKS interactive tutoring system. Journal of Computing Sciences in Colleges, 19(4), 342-347.

[59]. Hasselbring, T. S. (1988). Developing math automaticity in learning handicapped children: The role of computerized drill and practice. Focus on Exceptional Children, 20(6), 1-7.

[60]. Hurley, D. J., McBain, L., Harnisch, T. L., Parker, E., \& Russell, A. (2012). Top 10 higher education state policy issues for 2012. A Higher Education Policy Brief. 1, 1-6.

[61]. Johnson, D., Johnson, R., \& Smith, K. (1991). Active learning: Cooperation in the college classroom, Edina, MN: Interaction Brook Co.

[62]. Johnson, D., Johnson, R., \& Smith, K. (1991). Cooperative learning: Increasing college faculty instructional productivity (ASHE-ERIC Higher Education Report No. 4). Washington, DC: The George Washington University.

[63]. Jones, L. (1991). Using cooperative learning to teach statistics. (Research Report Number 91-2). University of North Carolina: The L.L. Thurstone Psychometric Laboratory.

[64]. Juan, A. A., Steegmann, C., Huertas, A., Martinez, J., \& Simosa, J. (2011). Teaching mathematics online in the european area of higher education: An instructor's point of view. International Journal of Mathematical Education in Science and Technology, 42(2), 141-153.

[65]. Kendricks, K. D. (2011). Creating a supportive environment to enhance computer-based learning for underrepresented minorities in college algebra classrooms. Journal of the Scholarship of Teaching and Learning, $11(4), 12-25$.

[66]. Kezar, A. (2011). What is the best way to achieve broader reach of improved practices in higher education? Springer Science Business Media, 36, 235-247.

[67]. Lesser, L. (2007). Using graphing calculators to do statistics: A pair of problematic pitfalls. Mathematics Teacher, 100, 375-378.

[68]. Lewis, A. S. (2013). Dispelling myths: Personalized learning tools will not replace teachers. VentureBeat.Mobilebeat 2013. Retrieved from http://venturebeat.com/ 2013/04/26/dispelling-mythspersonalized-learning-tools-will-notreplace-teachers/.

[69]. Litterman, R. B. (2014, May 13). Higher Education Price Index. Home. Retrieved from http://www.commonfund.org/CommonfundInstitute/HEPI /Pages/default.aspx.

[70]. Li, Z., Cheng, Y., \& Liu, C. (2013). A constructionism framework for designing game-like learnings systems: Its effect on different learners. British Journal of Educational Technology, 44(2), 208-224.

[71]. Loredo, G. (2012). Agenda item VI-G. Retrieved from http://www.thea.state.tx. us/generalpubs/agenda/ag2012_04/VIG/VIGSR.pdf.

[72]. Lucas, L., Postma, C., \& Jay, C. (1974). A comparative study of cognitive retention using simulation-gaming as opposed to lecture-discussion technique. Peabody Journal of Education, 52(4), 261-266.

[73]. McFadden, C. (2012). Are textbooks dead? Making sense of the digital transition. Publishing Research Quarterly, 28, 93-99.

[74]. McKeachie, W., Pintrich, P., Yi-Guang, L., \& Smith, D. (1986), Teaching and Learning in the College Classroom: A Review of the Research Literature. Ann Arbor, MI: Regents of the University of Michigan.

[75]. Mergel, B. (1988). Instructional design \& learning theory. Retrieved from http://www.U.S.sk.ca/education/coursework/802papers/mergel/brenda.htm.

[76]. Miller, D. E., \& Kunce, J. T. (1973). Prediction and statistical overkill revisited. Measurement and Evaluation in Guidance, 6(3), 157-163.

[77]. Mireles, S. (2014). Developmental mathematics. Texas State University. Retrieved from http://www.math.txstate.edu/devmath/.

[78]. National Council of Teachers of Mathematics (1989). Curriculum and evaluation standards for school mathematics. Reston, VA: National Council of Mathematics. 
[79]. Olszewski-Kubilius, P., \& Lee, S. (2011). Gender and other group differences in performance on off-level test: Changes in the 21st century. Gifted Child Quartely, 55(1), 54-73.

[80]. Pappas, C. (2014). Wearable technology in the classroom infographic - e-learning infographics. eLearning Infographics. Retrieved from http://elearninginfographics.com/ wearable-technology-in-the-classroominfographic.

[81]. Peters, M. L. (2013). Examining the relationships among classroom climate, self-efficacy, and achievement in undergraduate mathematics: A multi-level analysis. International Journal of Science and Mathematics Education, 11(2), 459-480.

[82]. Pitre, P. E. (2011). P-20 education policy: School to college transition policy in Washington state. Education Policy Analysis Archives, 19(5), 1-14.

[83]. Powell, B. A., Gilleland, D. S., \& Pearson, L. C. (2012). Expenditure, efficiency, and effectiveness in U.S. undergraduate higher education: A nation benchmark model. The Journal of Higher Education, 83(1), 102-127.

[84]. Sáinz, M., \& Eccles, J. (2012). Self-concept of computer and math ability: Gender implications across time and within ICT studies. Journal of Vocational Behavior, 80(2), 486-499.

[85]. Salkind, N. J. (Ed.). (2010). Encyclopedia of research design (Vol. 1). Thousand Oaks, CA: Sage.

[86]. Salnikov, N., \& Burukhin, S. (2009). Current state and problems of higher education reform. Russian Education and Society, 51(11), 71-89.

[87]. Scheaffer, R. L., Mendenhall III, W., \& Ott, L. R. (2006). Elementary survey sampling (6 ${ }^{\text {th }}$ ed.). Belmont, CA: Thompson Brooks/Cole.

[88]. Schreyer-Bennethum, L., \& Albright, L. (2011). Evaluating the incorporation of technology and applications projects in higher education mathematics classrooms. International Journal of Mathematics Education in Science and Technology, 42(1), 53-63.

[89]. Shaughnessy, J. M. (1977), Misconceptions of Probability: An experiment with a small-group activity-based model building approach to introductory probability at the college level. Educational Studies in Mathematics, 8, 285-316.

[90]. Soares, L. (2011). The 'personalization' of higher education. Center for American Progress. Retrieved from http://www.americanprogress.org/issues/labor/report/ 2011/10/04/10484/the-personalization-ofhigher-education/.

[91]. Stahl, C. (2011). Knowledge space theory: 2008-06-18. [Report No. 2009-12-22]. Retrieved from http://cran.itam.mx/web/packages/kst/vignettes/kst.pdf.

[92]. Starkweather, J., \& Moske, A. K. (2011). Multinomial logistic regression. Retrieved from:

[93]. http://www.unt.edu/rss/class/Jon/Benchmarks/MLR_JDS_Aug2011.pdf.

[94]. Taylor, J. (2008). The effects of a computerized-algebra program on mathematics achievement of college and university freshmen enrolled in a developmental mathematics course. Journal of College Reading and Learning, 39(1), 35-50.

[95]. Tinto, V. (1975). Dropout from higher education: A theoretical synthesis of research. Review of Educational Research, 45(1). 89-125.

[96]. Tinto, V. (1999). Taking retention seriously: Rethinking the first year of college. NACADA Journal, 19(2), 5-9.

[97]. Tóth, Z. (2007). Mapping students' knowledge structure in understanding density, mass, percent, molar mass, molar volume and their application in calculations by the use of the knowledge space theory. Chemistry Education Research and Practice, 8(4), 376-389.

[98]. Traxler, J. (2007). Defining, discussing and evaluating mobile learning: The moving finger writes and having writ... International Review of Open and Distance Learning, 8(2).

[99]. Urban-Lurain, M. (2004). Intelligent tutoring systems: An historic review in the context of the development of artificial intelligence and educational psychology. Retrieved from http://www.cse.msu.edu/rgroups/cse101/ITS/its.htm.

[100]. Varsavsky, C. (2010). Chances of success in and engagement with mathematics for students who enter university with a weak mathematics background. International Journal of Mathematics in Science and Technology, 41(8), 1037-1049.

[101]. Vygotsky, L. (1987). Mind in society: The development of higher psychological processes. Cambridge, MA: Harvard University Press.

[102]. Walcott, C., \& Walcott, A. (1976). Simple simulations: A guide to the design and use of simulation/games in teaching political science. Washington, D.C: American Political Science Association.

[103]. Zakaria, E., Chin, L. C., \& Daud, M. Y. (2010). The effects of cooperative learning on students' mathematics achievement and attitude towards mathematics. Journal of Social Sciences, 6(2), 272. 